\title{
Adrenal Medulla Grafts in the Hemiparkinsonian Rat: Profile of Behavioral Recovery Predicts Restoration of the Symmetry between the Two Striata in Measures of Pre- and Postsynaptic Dopamine Function
}

\author{
Eileen J. Curran,' Roger L. Albin, ${ }^{1,2}$ and Jill B. Becker ${ }^{1,3}$ \\ 'Neuroscience Program, '2Department of Neurology, and ${ }^{3}$ Department of Psychology, The University of Michigan, Ann \\ Arbor, Michigan 48104
}

Following unilateral striatr' dopamine depletion, the hemiparkinsonian rat exhibits rotational behavior in response to amphetamine and apomorphine. The rotational behaviors induced by these drugs are thought to reflect an asymmetry in presynaptic striatal dopamine release and an asymmetry in postsynaptic striatal dopamine receptor function, respectively. Grafts of adrenal medulla cells in the lateral ventricle of hemiparkinsonian rats have been reported to reduce behavioral asymmetry. More than one profile of behavioral recovery, however, is observed. Some animals show a graftinduced decrease only in the response to apomorphine, but others show a decrease in the response to amphetamine, and still others show a decrease in the behavioral responses to amphetamine and apomorphine. In this report, amphetamine- and apomorphine-induced turning behaviors were determined in hemiparkinsonian rats prior to and following intraventricular grafts of adrenal medulla or control tissue. Both bilateral intrastriatal microdialysis in freely moving animals and quantitative dopamine receptor autoradiography procedures were conducted in each animal so as to determine the relations between pre- and postsynaptic dopaminergic measures as well as the association between these measures and the different profiles of behavioral recovery after adrenal medulla grafts.

We report here that in animals with an adrenal medulla graft-induced decrease in the behavioral response to amphetamine, the balance between the two striata in extracellular striatal dopamine concentrations and $D_{2}$ dopamine receptor binding was restored. Furthermore, enhanced extracellular striatal dopamine concentrations were highly correlated with the graft-induced symmetry in striatal $D_{2}$ dopamine receptor binding. In contrast to animals with decreased amphetamine-induced turning, in animals with a

Received Sept. 24, 1992; revised Mar. 1, 1993; accepted Mar. 15, 1993.

We thank Dr. S. P. Kwak and Dr. S. J. Watson (The University of Michigan) for their generous contribution of the tyrosine hydroxylase cRNA probe and corresponding sense probe. We thank Dr. A. B. Young, Dr. J. B. Penney, and Z. Hollingsworth for their assistance with the dopamine receptor autoradiography assays. This research was supported by a grant from the U.S. Public Health Service to J.B.B. (NS22157), who is the recipient of a Research Career Development Award (NS01056). This research was conducted in partial fulfillment of the requirements for the Ph.D. by E.J.C.

Correspondence should be addressed to Dr. J. B. Becker, The University of Michigan, Neuroscience Laboratory Building, 1103 East Huron Street, Ann Arbor, MI 48104-1687.

Copyright (C) 1993 Society for Neuroscience $0270-6474 / 93 / 133864-14 \$ 05.00 / 0$ graft-induced decrease exclusively in response to apomorphine, the presynaptic symmetry was not restored and there was a significantly smaller effect on $D_{2}$ receptor binding. We conclude that those animals that show decreased amphetamine-induced turning after adrenal medulla grafts had the most effective grafts, and suggest that methods designed to optimize this behavioral profile are most likely to lead to enhanced clinical efficacy with this procedure.

[Key words: microdialysis, dopamine, rotational behavior, dopamine receptor binding, adrenal medulla grafts, amphetamine, apomorphine, striatum, Parkinson's disease]

The loss of dopamine (DA) input to the striatum from the substantia nigra is the major factor contributing to the clinical features of Parkinson's disease. This disorder is characterized by symptoms of bradykinesia, rigidity, resting tremor, and loss of postural reflexes (Weiner and Lang, 1989). The bilateral destruction of substantia nigra DA neurons by the neurotoxin 6-hydroxydopamine (6-OHDA) produces symptoms in the rat that are analogous to Parkinson's disease (Zigmond et al., 1990). The animals are extremely debilitated, however, so rats with unilateral striatal DA denervation are used as an alternative animal model. Following unilateral destruction of substantia nigra DA neurons by 6-OHDA, the hemiparkinsonian rat exhibits quantifiable functional asymmetries including contralateral sensorimotor neglect, contralateral resting tremor of the vibrissae, postural deviation, and spontaneous turning toward the lesion side (Ungerstedt, 197 la,b; Marshall, 1979; Buonamici et al., 1986). The spontaneous turning behavior dissipates with time following the lesion, but the functional asymmetry can be re-exposed using drugs that stimulate DA activity. For example, both amphetamine and apomorphine induce rotational behavior in the hemiparkinsonian rat (Ungerstedt, 1971a,b; Pycock, 1980; Glick and Shapiro, 1985).

Amphetamine stimulates DA release and blocks DA reuptake by the presynaptic terminals. In rats with unilateral lesions of the substantia nigra pars compacta, the intact striatum has a greater number of nigrostriatal DA terminals than does the denervated striatum, producing an asymmetry between the two striata. Systemic amphetamine treatment results in rotational behavior away from the intact side and toward the lesion side (Ungerstedt, 1971a; Pycock, 1980; Robinson and Becker, 1983). This ipsiversive turning behavior has been used extensively as a behavioral measure of the asymmetry in presynaptic striatal DA function. In contrast to amphetamine, a systemic injection 
of apomorphine produces rotational behavior in the direction away from the denervated striatum. Apomorphine is a DA receptor agonist, acting at both $\mathrm{D}_{1}$ and $\mathrm{D}_{2}$ DA receptor subtypes. The contraversive rotational behavior induced by apomorphine has been attributed to postsynaptic DA receptor supersensitivity that occurs following DA denervation (Ungerstedt, $1971 \mathrm{~b}$; Creese et al., 1977). One conventional measure of postsynaptic DA receptor supersensitivity in the hemiparkinsonian rat is the upregulation of $\mathrm{D}_{2} \mathrm{DA}$ receptors within the denervated striatum, and this measure is thought to be correlated with the magnitude of a pomorphine-induced rotational behavior (Creese et al., 1977). The contraversive turning induced by apomorphine, therefore, has been used as a behavioral measure of the asymmetry in striatal postsynaptic DA receptor function.

Intraventricular adrenal medulla grafts have been found to decrease both amphetamine- and apomorphine-induced rotational behavior in rats with unilateral striatal DA depletions (Freed et al., 1981; Becker and Freed, 1988a). A decrease in the rotational behavior induced by either drug is thought to reflect the restoration of functional symmetry across the two striata, and has been interpreted as behavioral recovery of function. The mechanisms by which adrenal medulla grafts ameliorate these behavioral symptoms are currently topics of investigation. A prevailing hypothesis suggests that a graft-induced decrease in the rotational behavior induced by amphetamine and a decrease in the behavior induced by apomorphine would result if changes in both pre- and postsynaptic function are occurring simultaneously. It has been proposed that intraventricular adrenal medulla grafts supply DA to the denervated striatum. The graft-derived DA would then act as a new source for presynaptic DA and thus decrease the presynaptic asymmetry; the interaction of the graft DA with the postsynaptic DA receptors would decrease the receptor supersensitivity and thus the postsynaptic asymmetry. We have recently found, however, that intraventricular adrenal medulla grafts can independently affect rotational behaviors induced by amphetamine versus apomorphine (Becker et al., 1990a; Curran and Becker, 1991). Specifically, some animals exhibit a graft-induced decrease in the behavioral responses both to amphetamine and to apomorphine, but others show a graft-induced decrease in the response only to amphetamine or only to apomorphine. The ability of intraventricular adrenal medulla grafts to promote a decrease in only one behavior would suggest, therefore, that the mechanisms reestablishing the symmetry in presynaptic DA function between the intact and DA-denervated striatum are independent of the mechanisms reestablishing the symmetry in postsynaptic DA function.

The aim of the present study was to determine if intraventricular adrenal medulla grafts affect the balance in presynaptic DA function between the two striata independently from the balance in postsynaptic DA function in hemiparkinsonian rats. The symmetry in presynaptic DA function between the intact and DA-denervated striatum was analyzed behaviorally with amphetamine and neurochemically using bilateral in vivo microdialysis. The symmetry in postsynaptic function was analyzed with apomorphine-induced rotational behavior and quantitative in vitro DA receptor autoradiography. All of these measures were conducted in the same animals so that the relationships among the behavior, neurochemistry, and receptor binding could be directly analyzed. Our findings indicate that animals with a graft-induced recovery of the behavioral response to amphetamine also have normalized presynaptic and post- synaptic striatal DA symmetries assessed by in vivo microdialysis and DA receptor binding; those animals with a graftinduced decrease in the behavioral response to apomorphine do not have these symmetries restored. Furthermore, the amelioration of asymmetry in postsynaptic striatal $D_{2} D A$ receptor binding was highly correlated with the restoration of presynaptic DA function but not with the behavioral response to apomorphine. By examining the different measures of recovery of function in the same animals, we are able to determine the extent that these measures are related. The association of normalized presynaptic striatal DA release and postsynaptic striatal $\mathrm{D}_{2} \mathrm{DA}$ receptor binding with decreased amphetamine-induced turning suggests that research focused on the mechanisms promoting this type of behavioral recovery will be beneficial in both the clinical and basic research settings.

\section{Materials and Methods}

Surgery and behavioral testing. Adult female Long-Evans rats (180-200 $\mathrm{gm}$ ) were maintained on a 14:10 hr (light:dark) cycle with food and water continuously available. All experimental procedures were conducted in accordance with an approved University Committee on Use and Care of Animals protocol. The surgical and behavioral procedures used in this study have been described in detail previously (Curran and Becker, 1991). Briefly, the animals were tested for a rotational bias with $0.85 \mathrm{mg} / \mathrm{kg}$ amphetamine (Robinson and Becker, 1983). Each animal received a unilateral infusion of $6-\mathrm{OHDA}-\mathrm{HBr}(8 \mu \mathrm{g} / 4 \mu \mathrm{l}$ at $0.5 \mu \mathrm{l} / \mathrm{min})$ into the substantia nigra contralateral to the preferred direction of rotation during the amphetamine tests. Two weeks later the rats were screened for complete lesions with $0.25 \mathrm{mg} / \mathrm{kg}$ apomorphine (s.c., $1 \mathrm{hr}$ ) and then $0.85 \mathrm{mg} / \mathrm{kg}$ amphetamine (i.p., $1 \mathrm{hr}$ ). Those animals that passed criteria (Curran and Becker, 1991) were repeatedly treated with amphetamine to sensitize and stabilize the rotational behavior induced by this drug (Robinson et al., 1982). Following the amphetamine sensiti zation, the rats underwent pregraft rotational behavior testing with 0.1 $\mathrm{mg} / \mathrm{kg}$ apomorphine (s.c.). One hour tests were separated by $48 \mathrm{hr}$ and conducted until rotational behavior stabilized (three to six tests). The testing schedule was then repeated for rotational behavior induced by $3.0 \mathrm{mg} / \mathrm{kg}$ amphetamine (i.p., $2 \mathrm{hr}$ tests).

Following the pregraft rotational testing with both apomorphine and amphetamine, the rats received intraventricular adrenal medulla grafts $(n=34)$ or intraventricular adrenal cortex grafts $(n=8)$, or remained as lesion-only controls ( $n=12$; four of these animals were tested for rotational behavior as though they had received a graft). The graft tissue was obtained from female Long-Evans rats as previously described (Curran and Becker, 1991). Starting at 6 weeks postgraft, the animals were tested once a week with $0.1 \mathrm{mg} / \mathrm{kg}$ apomorphine ( $1 \mathrm{hr}$ test) and $48 \mathrm{hr}$ later with $3.0 \mathrm{mg} / \mathrm{kg}$ amphetamine $(2 \mathrm{hr}$ test). The postgraft testing continued until 22 weeks postgraft $(n=5)$ or until 10 weeks postgraft $(n=41)$. The mean of the number of $360^{\circ}$ turns induced in the last three postgraft behavioral tests for each drug was compared with the pregraft mean to calculate the percentage change in rotational behavior [(postgraft - pregraft)/pregraft $\times 100 \%]$.

Rotational behavior and group assignment. Animals with adrenal medulla grafts $(n=34)$ were assigned to one of three groups based on their behavioral recovery. Animals that had at least a $10 \%$ decrease in a druginduced behavior postgraft were considered to express recovery in response to that drug (Becker et al., 1990a). Six animals with adrenal medulla grafts had graft-induced decreases in the responses to both amphetamine and apomorphine, 3 animals exhibited a decrease only in the response to amphetamine, 13 animals showed a decrease only in the response to apomorphine (APO RECOV), and 12 animals did not show any behavioral recovery (NO RECOV). All animals with an adrenal medulla graft that exhibited at least a $10 \%$ decrease in the behavioral response to amphetamine have been considered as one group throughout this study (AMPH RECOV; $n=9$ ). The AMPH RECOV animals that showed decreases in both amphetamine- and apomorphine-induced turning $(n=6)$ were treated as a separate group from those that showed only a decrease in amphetamine-induced turning ( $n$ $=3$ ) for initial comparisons. On all neurochemical and binding measures, however, there was complete overlap between these two groups, and so they were combined for all analyses reported here. Table 1 
Table 1. Amphetamine- and apomorphine-induced rotational behavior

\begin{tabular}{|c|c|c|c|c|}
\hline \multirow[b]{2}{*}{ Group } & \multicolumn{2}{|c|}{$3.0 \mathrm{mg} / \mathrm{kg}$ Amphetamine } & \multicolumn{2}{|c|}{$0.1 \mathrm{mg} / \mathrm{kg}$ Apomorphine } \\
\hline & Pregraft $^{a}$ & $\begin{array}{l}\text { Postgraft as } \\
\% \text { change from } \\
\text { pregraft }\end{array}$ & Pregraft $^{b}$ & $\begin{array}{l}\text { Postgraft as } \\
\% \text { change from } \\
\text { pregraft }\end{array}$ \\
\hline AMPH RECOV $(n=9)$ & $1762 \pm 289$ & $-22.3 \pm 9.6^{c}$ & $238 \pm 75$ & $-11.3 \pm 8.7$ \\
\hline APO RECOV $(n=13)$ & $2154 \pm 218$ & $20.7 \pm 8.35$ & $435 \pm 75$ & $-22.5 \pm 2.1^{c}$ \\
\hline NO RECOV $(n=12)$ & $1991 \pm 175$ & $19.0 \pm 7.1$ & $321 \pm 38$ & $12.0 \pm 7.4$ \\
\hline Cortex graft $(n=8)$ & $1898 \pm 176$ & $9.3 \pm 7.2$ & $383 \pm 54$ & $8.9 \pm 6.8$ \\
\hline Lesion only ${ }^{d}$ & $1863 \pm 192$ & $23.1 \pm 10.7$ & $426 \pm 60$ & $7.9 \pm 11.3$ \\
\hline
\end{tabular}

Data are presented as mean \pm SEM

" Total number of rotations $\left(360^{\circ}\right.$ turns) made in a 2 hour test session pregraft. No significant difference was seen among the groups $[F(4,49)=0.458 ; p=0.732]$.

"Total number of rotations made in a 1 hour test session pregraft. No significant difference was seen among the groups $[F(4,49)=1.506 ; p=0.186]$

' The percentage decrease in amphetamine-induced turning for the AMPH RECOV group and the percentage decrease in apomorphine-induced lurning for the APO RECOV group are highlighted to stress the difference in behavioral recovery across groups.

"Pregraft testing for lesion-only groups $(n=12)$; postgraft testing for lesion-only group $(n=4)$.

illustrates the percentage change from pregraft rotational behavior for three behaviorally distinct groups of animals with intraventricular adrenal medulla grafts compared to animals with intraventricular adrenal cortex grafts $(n=8)$ and lesion-only controls $(n=4)$. Pregraft rotational behavior induced by amphetamine and apomorphine did not differ among the five groups with unilateral substantia nigra lesions (Table 1).

Within the two unilaterally DA-denervated control groups (adrenal cortex grafted and lesion-only), only one of the eight adrenal cortexgrafted animals and none of the lesion-only animals showed a greater than $10 \%$ decrease in amphetamine-induced turning. A different adrenal cortex-grafted animal had a greater than $10 \%$ decrease in apomorphineinduced turning postgraft. It should be noted, however, that the neurochemical and binding data of these two animals were not different from the other control animals and are included in the data reported. Furthcrmorc, while all the animals were sensitized to amphetamine prior to the pregraft behavioral testing, there was still a tendency for all the groups except the AMPH RECOV group to express an increase in this behavior during postgraft testing. This is most likely due to the progressive nature of the sensitization phenomena; the more drug the animals are exposed to, the greater the sensitization. It is also possible that there is some drug-environment conditioning contributing to the enhancement of rotational behavior in some animals (see Robinson and Becker, 1986, for a review).

In vivo microdialysis in freely moving animals. Following the postgraft rotational behavior tests, all the animals with unilateral substantia nigra lesions, plus five nonlesioned intact animals (INTACT) that underwent similar drug treatments, received implants of two guide cannulas aimed bilaterally at the denervated and intact striata. The animals were anesthetized with sodium pentobarbital $(30 \mathrm{mg} / \mathrm{kg}$ ) supplemented with methoxyflurane and two burr holes were drilled $+0.2 \mathrm{~mm}$ anterior and $\pm 2.0 \mathrm{~mm}$ lateral from bregma. Two 21 gauge guide cannulas were lowered $1.0 \mathrm{~mm}$ from top of skull (skull flat) and secured in place with dental acrylic. The guide cannulas were kept patent with a 26 gauge stylet until use. At least 1 week later dialysis probes were lowered through the guide cannulas into the two striata and the animals underwent in vivo microdialysis $12-18 \mathrm{hr}$ later. The dialysis probe was of a concentric design adapted from Robinson and Camp (1991). The dialysis membrane was $4 \mathrm{~mm}$ in length with a $250 \mu \mathrm{m}$ outer diameter and a MW cutoff of 6000 . Sixteen to eighteen hours following implantation, the dialysis experiments began. Throughout the experiment a Ringer's solution (145 mM NaCl, $2.7 \mathrm{mM} \mathrm{KCl}, 1.2 \mathrm{mM} \mathrm{CaCl}_{2}$, and $1.0 \mathrm{mM} \mathrm{MgCl}_{2}$; $\mathrm{pH} 7.3$ ) was pumped through the probe at $1.5 \mu \mathrm{l} / \mathrm{min}$ and dialysate samples were collected at 20 min intervals from freely moving animals. Samples were taken until stable basal striatal DA concentrations were obtained. All samples were analyzed for DA and dihydroxyphenylacetic acid (DOPAC) using HPLC with coulometric detection. Once basal DA and DOPAC concentrations were established in both the intact and DAdenervated striatum, the animals received a systemic injection of 3.0 $\mathrm{mg} / \mathrm{kg}$ amphetamine (i.p.) and dialysate samples were collected for an additional $160 \mathrm{~min}$. The dialysis data from just the denervated striatum (but not from the contralateral intact striatum) of 13 of the 34 rats with adrenal medulla grafts and 2 of the 8 rats with adrenal cortex grafts have been previously presented (Curran and Becker, 1991).

$D_{1}$ and $D_{2} D A$ receptor autoradiography. At least 1 month after the completion of all behavioral testing and the in vivo microdialysis procedure (to avoid possible confounding effects of drug treatment), all animals were decapitated and the brains were removed and quickly frozen on dry ice. This was approximately 8-10 months after the initiation of the experiment and $2-4$ months after the last behavioral test This interval did not vary by group, nor was it correlated with graft survival. Five nonlesioned intact animals (INTACT) of the same age that received drug treatment hut did not undergo dialysis were added to this part of the experiment. The brains were then stored at $-70^{\circ} \mathrm{C}$ until processed for $D_{1}$ and $D_{2}$ DA receptor autoradiography (Richfield et al., 1987) and tyrosine hydroxylase (TH) mRNA in situ hybridization (see below). Twenty micrometer coronal sections were cut through the rostrocaudal extent of the striatum. Representative sections through the substantia nigra were also collected and utilized in the in situ hybridization experiments to confirm the analysis of lesion size with cell counts discussed below. The sections were cut on a cryostat maintained at $-15^{\circ} \mathrm{C}$ and thaw mounted onto $2 \times$ chrom-alum-subbed slides. Alternate sections from each brain were used for the $D_{1}$ and $D_{2}$ assays. Every third section was mounted onto poly-L-lysine-subbed slides and stored at $-70^{\circ} \mathrm{C}$ until processed for TH mRNA in situ hybridization.

The buffer solution for both the $D_{1}$ and $D_{2}$ binding density assays contained $25 \mathrm{~mm}$ Tris- $\mathrm{HCl}(\mathrm{pH} 7.5), 100 \mathrm{nM} \mathrm{NaCl}, 1 \mathrm{~mm} \mathrm{MgCl}, 1 \mu \mathrm{M}$ pargyline, and $0.001 \%$ ascorbate. Prior to incubation, the tissue sections were warmed to room temperature. The slides were then incubated in the appropriatc tritiated ligand-buffer solution for $2.5 \mathrm{hr}$ at room temperature. This was followed by a $10 \mathrm{~min}$ wash in buffer at $4^{\circ} \mathrm{C}$ and a 3 sec dip in distilled water at $4^{\circ} \mathrm{C}$; the sections were then dried under a cool stream of air.

The $\mathrm{D}_{1}$ assay contained ${ }^{3} \mathrm{H}-\mathrm{SCH} 23390$ (Amersham; $83 \mathrm{Ci} / \mathrm{mmol}$ ) at a concentration of $550 \mathrm{pM}$. Nonspecific binding was determined by the addition of $1 \mu \mathrm{M}$ cis-flupentixol to the ligand-buffer solution. The $\mathrm{D}_{2}$ assay contained ${ }^{3} \mathrm{H}$ spiperone (Amersham; $93 \mathrm{Ci} / \mathrm{mmol}$ ) at a concentration of $250 \mathrm{pM}$ in the presence of $100 \mathrm{nM}$ mianserin to block binding to the 5-HT type 2 receptor. Nonspecific binding was determined by the addition of $10 \mu \mathrm{M} \mathrm{DA}$. $\mathrm{D}_{2}$ saturation experiments were also conducted on a subset of the animals used in the above binding density experiments. These assays used the same buffer and incubation time with concentrations of ${ }^{3} \mathrm{H}$ spiperone (Amersham, $100 \mathrm{Ci} / \mathrm{mmol}$ ) from 0.05 to $2.5 \mathrm{~nm}$.

The dried slides from each assay were placed in X-ray cassettes with ${ }^{14} \mathrm{C}$ standards and apposed to $\mathrm{LKB}$ Ultrofilm ${ }^{3} \mathrm{H}$ for 3 weeks $\left(\mathrm{D}_{1}\right.$ assay) or 4 weeks $\left(D_{2}\right.$ assay). The ${ }^{14} \mathrm{C}$ standards were calibrated for ${ }^{1} \mathrm{H}$ concentrations as described by Pan et al. (1983). All binding data were determined directly from film densities. Films were analyzed using a photographic enlarger and a computer to determine optical densities (Richfield et al., 1987). The striatum was divided into four quadrants 
(dorsomedial, dorsolateral, ventromedial, and ventrolateral) to assess regional differences in binding densities. A computer-generated polynomial regression analysis used the mean of readings from each area to determine the amount of ${ }^{3} \mathrm{H}$ label bound per milligram of protein.

$T H m R N A$ in situ hybridization. The in situ hybridization experiments utilized a TH oligonucleotide (New England Nuclear) according to standard techniques (Watson et al., 1988). Briefly, the sections were removed from $-70^{\circ} \mathrm{C}$ and placed into $4 \%$ paraformaldehyde for $1 \mathrm{hr}$ at room temperature. The sections were washed with phosphate-buffered saline, treated with acetic anhydride, and dehydrated through graded alcohols. Control sections were pretreated with $200 \mu \mathrm{g} / \mathrm{ml}$ RNase A. The TH probes were labeled with ${ }^{35} \mathrm{~S}$ using a New England Nuclear oligonucleotide $3^{\prime}$ end labeling system and ${ }^{35} \mathrm{~S}-\mathrm{dATP}$. The ${ }^{35} \mathrm{~S}-\mathrm{TH}$ probes were diluted with hybridization buffer (Watson et al., 1988) to give 3 $\times 10^{5} \mathrm{dpm} / 30 \mu \mathrm{l}$. Thirty microliters of buffer were added to coverslips; the coverslips were then placed over the sections and secured with rubber cement. The sections were incubated in moist chambers overnight at $37^{\circ} \mathrm{C}$. The next day, the coverslips were removed and the sections were washed in decreasing salt concentrations. The slides were air dried and apposed to $\mathrm{x}$-ray film for $7 \mathrm{~d}$. Slides were then dipped in Kodak NTB-2 emulsion and stored in light-tight boxes for $2-4$ months. Following the development of the emulsion-dipped slides, representative sections were stained with hematoxylin and eosin to visualize the adrenal medulla or adrenal cortex grafts.

The brain from one animal with an adrenal medulla graft was processed using a TH riboprobe (donated by Drs. Kwak and Watson, The University of Michigan), and consecutive sections were processed with either the cRNA probe or the corresponding sense probe for controls. Ten micrometer sections were cut through the rostrocaudal extent of the striatum. Alternate sections were incubated with hybridization buffer containing either the antisense or sense $\mathrm{TH}$ riboprobe. A subgroup of the scctions were pretreated with RNase A. The pre- and posthybridization procedures were conducted as described by Watson et al. (1988).

Histology and cell counts. Histological analysis of dialysis probe placement consisted of cresyl violet-stained coronal sections at the level of the striatum. The dialysis data obtained from any probe not located within the striatum were dropped from the study. As mentioned above, the sections used in the $\mathrm{TH}$ in situ experiments were stained with hematoxylin and eosin, as were additional sections throughout the rostrocaudal extent of the striatum and lateral ventricles. These sections were examined for graft placement. Surviving grafts were analyzed for chromaffin cells.

Coronal sections at the level of the substantia nigra were also stained with cresyl violet and analyzed for lesion size. Analysis of lesion size was conducted using the fractionator method, a stereological technique described in detail by Gundersen et al. (1988). Briefly, both the intact and lesioned substantia nigra zona compacta of each animal were subdivided into three fractions (medial, mediolateral, and lateral) at two rostrocaudal levels. A random subpopulation of the medium-sized dopaminergic neurons $(15-20 \mu \mathrm{m})$ (Gulley and Wood, 1971) within a 250 $\times 250 \mu \mathrm{m}$ grid at $400 \times$ magnification were then counted. Cell counts within the substantia nigra of rats without 6-OHDA lesions were conducted to determine normal neuronal density. No difference was observed in cell numbers within the intact substantia nigra of unilaterally lesioned animals and those of rats without 6-OHDA lesions. The total number of cells within the lesioned substantia nigra of each animal was therefore expressed as a percentage decrease in number of cells relative to the contralateral (intact) side.

\section{Results}

In vivo microdialysis in freely moving animals

Basal extracellular DA and DOPAC concentrations in dialysate from both the denervated and intact striatum of the five groups with unilateral striatal DA denervations are shown in comparison to values obtained bilaterally from nonlesioned, INTACT animals $(n=5)$ in Figure 1 . The data from the left and right striata of the INTACT animals were randomly assigned to the denervated and intact groups (Fig. 1, left and right, respectively). A one-way ANOVA indicated that among the six groups that were identified by their graft and/or behavior, there was a significant difference within the DA-denervated striatum in both basal extracellular DA concentrations [Fig. $1 A ; F(5,41)=10.64$; $p=0.0001$ ] and basal extracellular DOPAC concentrations [Fig. $1 C ; F(5,41)=23.58 ; p=0.0001]$. Basal DA concentrations in dialysate from the DA-denervated striatum of the AMPH RECOV group $(n=7)$ were not significantly different from the INTACT animals $(n=5)$. In addition, both the AMPH RECOV group and the INTACT group had significantly higher basal extracellular DA concentrations $(p<0.05)$ than the denervated striatum of the APO RECOV $(n=12)$, NORECOV $(n=10)$, cortex-grafted $(n=8)$, and lesion-only groups $(n=5)$. Basal DOPAC concentrations in dialysate from the DA-denervated striatum were significantly lower in all groups with unilateral 6-OHDA lesions compared with INTACT animals $(p<0.05)$. However, the AMPH RECOV animals had significantly higher basal extracellular DOPAC concentrations within the denervated striatum than all other lesioned groups $(p<0.05)$. In contrast to the denervated striatum, no significant differences were found in basal DA concentrations [Fig. $1 B ; F(5,35)=0.95$; $p=0.46]$ or basal DOPAC concentrations [Fig. $1 D ; F(5,35)=$ $0.36 ; p=0.87$ ] in dialysate from the contralateral (intact) striatum among the six groups.

The effect of amphetamine on DA and DOPAC concentrations in dialysate from both the denervated and intact striatum of the six groups is shown in Figure 2. These groups differed in amphetamine-stimulated DA release within the denervated striatum as indicated by a significant main effect of group $[F(5,41)$ $=14.53 ; p=0.0001]$, an effect of time $[F(7,287)=37.09 ; p=$ $0.0001]$, and a group $\times$ time interaction $[F(35,287)=10.2 ; p$ $=0.0001]$. The amphetamine-stimulated increase in dialysate DA concentrations from the denervated striatum was significantly potentiated in the AMPH RECOV group (Fig. $2 A$ ). The AMPH RECOV animals had significantly higher extracellular DA concentrations within the denervated striatum at all eight time points following a systemic injection of $3.0 \mathrm{mg} / \mathrm{kg} \mathrm{am}$ phetamine compared to the APO RECOV, NO RECOV, cortexgrafted, and lesion-only groups $(p<0.05)$. Furthermore, the amphetamine-stimulated increase in dialysate DA concentrations in the AMPH RECOV group did not differ significantly from the values obtained from INTACT animals except at the 40 and the $60 \mathrm{~min}$ time intervals. The amphetamine-induced decrease in dialysate DOPAC concentrations from the denervated striatum was also significantly different among the six groups [Fig. $2 C$; main effect of group: $F(5,41)=21.77 ; p=$ 0.0001 ; effect of time: $F(7,287)=31.35 ; p=0.0001$; group $\times$ time interaction: $F(35,287)=17.18 ; p=0.0001]$. The DOPAC concentrations in dialysate from the INTACT group were significantly higher at all time points compared to the five groups with unilateral DA depletions $(p<0.05)$. The AMPH RECOV group did, however, express significantly higher extracellular DOPAC concentrations compared to the other DA-denervated groups at all but the last time point $(p<0.05)$. Within the contralateral intact striatum, the amphetamine-induced changes in dialysate DA [Fig. $2 B ; F(5,35)=1.03 ; p=0.42]$ and DOPAC [Fig. $2 D ; F(5,35)=0.34 ; p=0.89$ ] concentrations were not significantly different among the six groups.

\section{$D_{1}$ and $D_{2} D A$ receptor autoradiography}

Figure 3 illustrates the $D_{1}$ and $D_{2}$ DA receptor binding densities within the intact and DA-denervated striatum of the five groups with unilateral 6-OHDA lesions and INTACT animals. No significant difference in either the $D_{1}$ or $D_{2} D A$ receptor binding was observed between the left and right striatum of the INTACT animals. The data from the left striatum of these animals, there- 


\section{Dopamine-Denervated Striatum}

A)

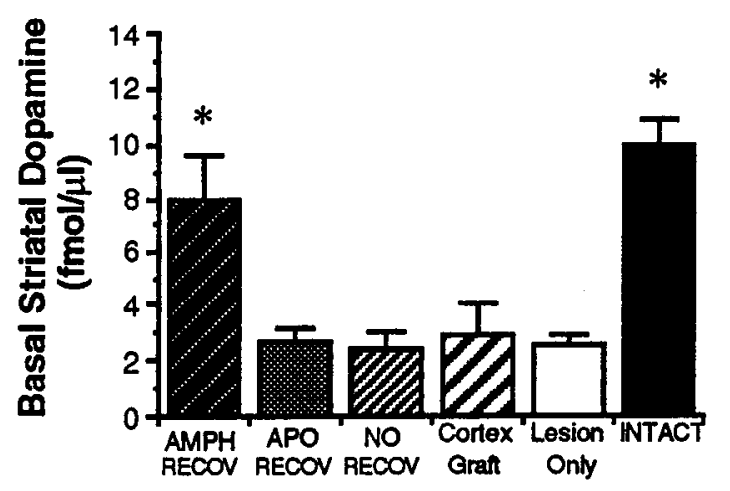

C)

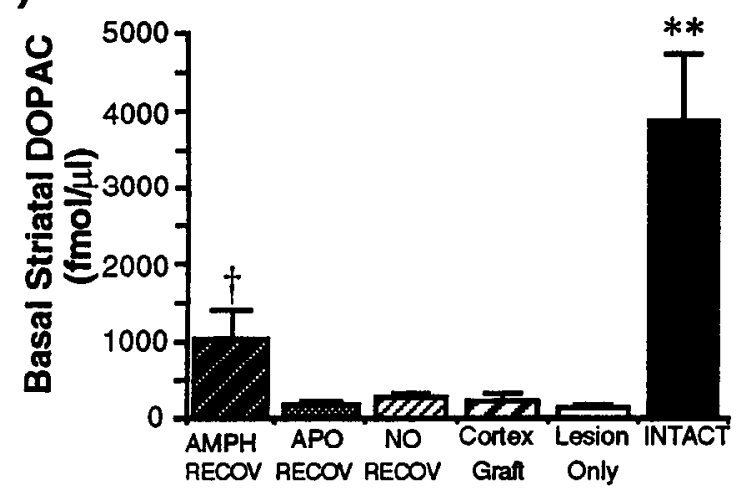

\section{Contralateral Intact Striatum}

B)

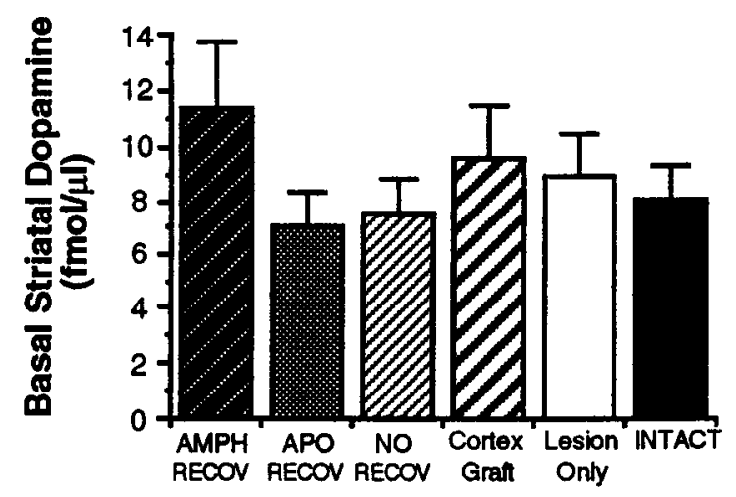

D)

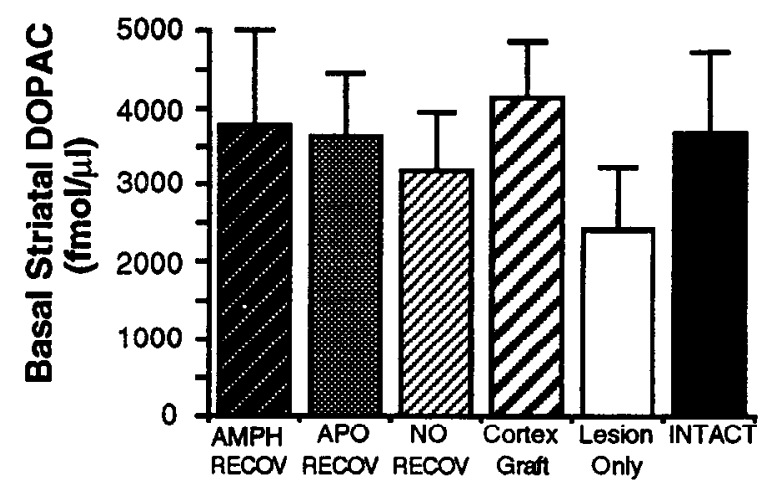

Figure 1. Basal extracellular DA and DOPAC concentrations in dialysate from the denervated and contralateral intact striatum of AMPH RECOV, APO RECOV, NO RECOV, cortex-grafted, lesion-only, and INTACT animals. There was a significant difference in basal extracellular DA $(A)$ and basal extracellular DOPAC $(C)$ concentrations within the denervated striatum among the six groups. *, Both AMPH RECOV and INTACT animals had significantly higher basal extracellular DA concentrations compared to the denervated striatum of APO RECOV, NO RECOV, cortex-grafted, and lesion-only animals $(p<0.05){ }^{* *}$, INTACT animals had higher basal extracellular striatal DOPAC concentrations than the denervated striatum of all five groups with unilateral striatal DA depletions $(p<0.05) . \dagger$, AMPH RECOV animals had significantly higher basal extracellular DOPAC concentrations within the denervated striatum compared to all other unilaterally lesioned groups $(p<0.05)$. There were no significant differences in either basal extracellular DA $(B)$ or basal extracellular DOPAC $(D)$ concentrations within the contralateral intact striatum among the groups.

fore, were used for analyses comparing the intact striatum across groups and the data from the right striatum were used in comparisons of the denervated striatum across groups. Unilateral 6-OHDA lesions of the substantia nigra did not affect striatal $D, D A$ receptor binding densities (Fig. $3 A$ ). Since we found no lesion effect on the striatal $D, D A$ receptor binding density, no further analyses of $D_{1} D A$ receptor binding were conducted. There was a significant effect of DA denervation and adrenal medulla grafts on $\mathrm{D}_{2} \mathrm{DA}$ receptor binding densities within the DA-denervated striatum [Fig. $3 B ; F(5,46)=4.465 ; p=0.0021$ ]. Analysis of $\mathrm{D}_{2} \mathrm{DA}$ receptor binding within the contralateral intact striatum across groups revealed no significant difference.

Comparisons were conducted on the percentage difference in $\mathrm{D}_{2}$ DA receptor binding between the intact and DA-denervated striatum of each animal [(denervated - intact)/intact $\times 100 \%$; Fig. 4]. The lesion-only animals $(n=10)$ expressed a $19.5 \%$ difference in $D_{2}$ DA receptor binding within the denervated striatum when the whole striatum was examined (Fig. $4 A$ ). This difference was significantly greater than the left/right differences observed in the INTACT animals $(p<0.05)$. Unilaterally DAdenervated animals with adrenal cortex grafts $(n=6)$ or adrenal medulla grafts and NO RECOV $(n=10)$ showed similar differences in $\mathrm{D}_{2} \mathrm{DA}$ receptor binding within the denervated striatum that were also significantly greater than INTACT animals $(p<0.05)$. The percentage difference in $\mathrm{D}_{2} \mathrm{DA}$ receptor binding for APO RECOV animals $(n=9)$ was significantly greater than INTACT animals $(p<0.05)$ but this effect appeared somewhat blunted ( $13 \%$ increase within the denervated striatum), and was significantly lower than that found in rats with NO RECOV ( $p$ $<0.05$ ). Interestingly, the percentage difference in $\mathrm{D}_{2} \mathrm{DA}$ receptor binding for animals with AMPH RECOV $(n=7)$ was not different from INTACT animals. Furthermore, in the AMPH 


\section{Dopamine-Denervated Striatum}

\section{Contralateral Intact Striatum}
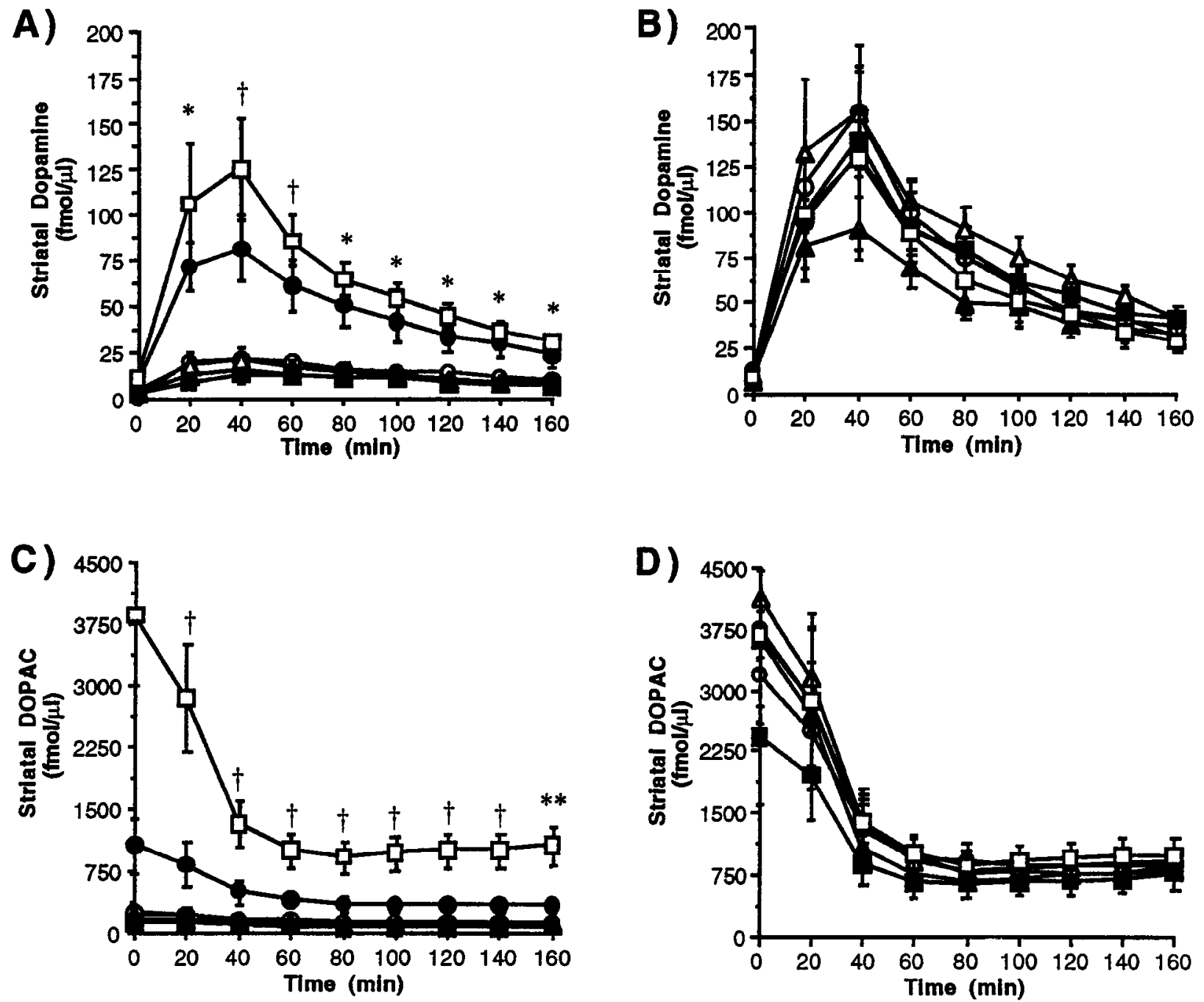

Figure 2. The effect of $3.0 \mathrm{mg} / \mathrm{kg}$ amphetamine on DA and DOPAC concentrations in dialysate from the denervated and contralateral intact striatum of AMPH KECOV (solid circles), APO RECOV (solid triangles), NO RECOV (open circles), cortex-grafted (open triangles), lesion-only (solid squares), and INTACT (open squares) animals. Basal extracellular DA and DOPAC concentrations (0 min) are shown in comparison to concentrations in eight 20 min dialysate samples following $3.0 \mathrm{mg} / \mathrm{kg}$ amphetamine (i.p.). There was a significant difference in amphetaminestimulated DA release $(A)$ and the amphetamine-stimulated decline in extracellular DOPAC $(C)$ within the denervated striatum among the six groups. *, AMPH RECOV animals were not significantly different from INTACT animals; both groups had significantly higher extracellular striatal DA concentrations compared to all other groups $(p<0.05)$. $\dagger$, AMPH RFCOV animals had significantly lower extracellular striatal DA and/or DOPAC concentrations than INTACT animals; both the AMPH RECOV and INTACT groups were significantly higher than all other groups ( $p$ $<0.05){ }^{* *}$, INTACT animals had higher extracellular striatal DOPAC concentrations compared to all other groups $(p<0.05)$. There was no significant difference in the amphetamine-stimulated DA release $(B)$ or the amphetamine-induced decline in extracellular DOPAC concentrations $(D)$ within the contralateral intact striatum among the six groups.

RECOV group the lesion/intact percentage difference in striatal $D_{2}$ DA receptor binding was significantly less than that observed in the lesion-only and NO RECOV animals $(p<0.05)$.

A breakdown of striatal $D_{2}$ DA receptor binding into quadrants revealed more striking effects of adrenal medulla grafts on the lesion-induced increase in $\mathrm{D}_{2} \mathrm{DA}$ receptor binding densities. In the dorsolateral striatum (Fig. $4 B$ ) a significant increase in $\mathrm{D}_{2} \mathrm{DA}$ receptor binding was found within the DA-denervated striatum of all five groups with unilateral striatal DA denervation compared to left/right differences in INTACT animals $(p<0.05)$. Analysis of the dorsomedial striatum, however, showed a normalization of $D_{2} \mathrm{DA}$ receptor binding in the AMPH RECOV animals (Fig. $4 C$ ), where AMPH RECOV animals were not significantly different from INTACT animals. In addition, the percentage difference in $\mathrm{D}_{2} \mathrm{DA}$ receptor binding found for the APO RECOV, NO RECOV, cortex-grafted, and lesion-only groups was significantly higher than both the AMPH RECOV and the INTACT groups $(p<0.05)$. The percentage difference in $\mathrm{D}_{2} \mathrm{DA}$ receptor binding in the ventromedial quadrant following a unilateral DA denervation was less than in the dorsal quadrants (Fig. 4D). Only the lesion-only, NO RECOV, and cortex-grafted animals had a significant increase compared to INTACT animals $(p<0.05)$. No significant difference was observed in $\mathrm{D}_{2}$ DA receptor binding within the ventrolateral quadrant across groups [data not shown; $F(5,46)=1.998 ; p=0.0967$ ].

Saturation analysis of ${ }^{3} \mathrm{H}$-spiperone binding revealed a $K_{d}$ of 
A)

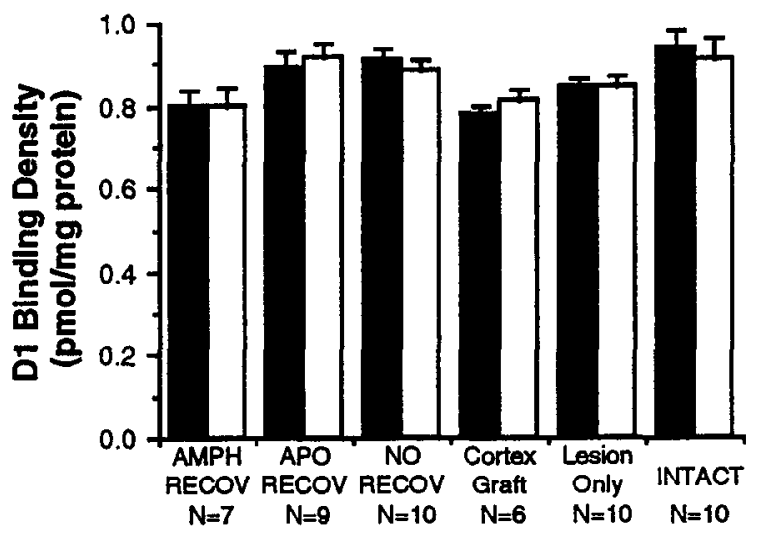

B)

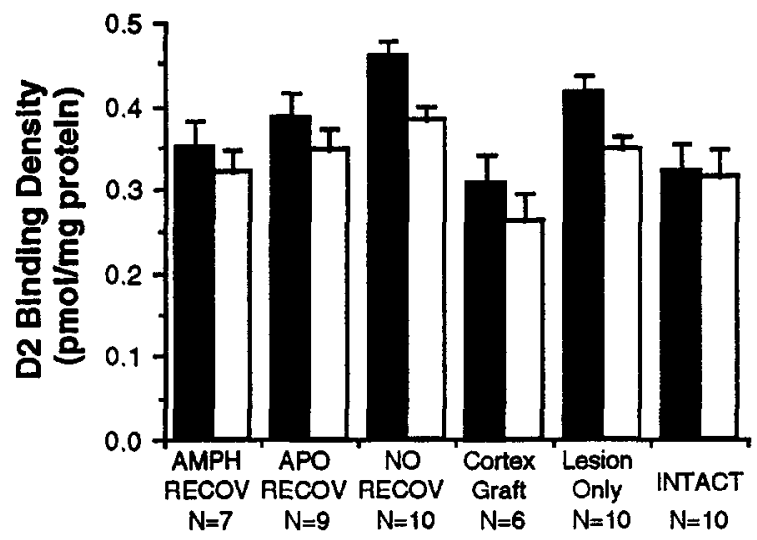

Figure 3. $\mathrm{D}_{1}$ DA receptor binding density assessed with ${ }^{3} \mathrm{H}-\mathrm{SCH} 23390$ $(A)$ and $\mathrm{D}_{2}$ DA receptor binding density assessed with ${ }^{3} \mathrm{H}$-spiperone $(B)$ within the denervated (solid bars) and contralateral intact (open bars) striatum. The five groups with unilateral 6-OHDA lesions are shown in comparison to INTACT animals. $A$, No significant lesion effect was observed in D, DA receptor binding densities within the denervated or contralateral intact striatum when the lesion-only animals were compared to INTACT animals. $B$, A one-way ANOVA revealed a significant difference in $\mathrm{D}_{2}$ DA receptor binding density within the denervated striatum among the six groups $[F(5,46)=4.47 ; p=0.002]$. Subsequent pairwise analysis indicated that lesion-only and NO RECOV animals had significantly higher $D_{2} D A$ receptor binding within the denervated striatum compared to INTACT animals $(p<0.05)$. No significant difference in $D_{2}$ DA receptor binding was observed within the contralateral intact striatum among the six groups $[F(5,46)=2.3 ; p=0.061]$.

$0.215 \pm 0.23 \mathrm{nM}$ and $\mathrm{a} B_{\max }$ of $0.615 \pm 0.036 \mathrm{pmol} / \mathrm{mg}$ protein within the INTACT group. No left/right differences were observed in these two values. Furthermore, no significant differences were seen in the raw values for either $K_{d}$ or $B_{\max }$ when compared across groups (Table 2). However, when the percentage differences in $B_{\max }$ between the intact and denervated striatum were compared across groups, a lesion and a graft effect was observed $[F(5,16)=3.36 ; p=0.029]$, similar to that observed in the $D_{2}$ binding density shown in Figure 4. Apparent differences between the saturation study and the single point binding density study may be due to the greater variance observed within groups for the saturation study.
Correlation analyses of behavior, neurochemistry, and receptor binding

Correlation analysis of the microdialysis data from the denervated striatum of the five groups with unilateral 6-OHDA lesions and the pcrcentage difference in $\mathrm{D}_{2} \mathrm{DA}$ reccptor binding density revealed that there is a significant correlation between the two measures. A comparison of amphetamine-stimulated DA release at 40 min postamphetamine (peak response) and $\mathrm{D}_{2}$ DA receptor symmetry within the dorsomedial striatum showed a high correlation $\left(R^{2}=0.431 ; p=0.0001\right)$, with the greatest extracellular DA concentrations being associated with the lowest percentage difference in $\mathrm{D}_{2}$ DA receptor binding, as can be seen in Figure $5 A$. Analysis of amphetamine-stimulated DA release and the symmetry in $\mathrm{D}_{2} \mathrm{DA}$ receptor binding for the whole striatum revealed a weaker correlation $\left(R^{2}=0.163 ; p=0.022\right)$. Basal extracellular DA concentrations within the denervated striatum were not correlated with the percentage difference in $D_{2}$ DA receptor binding when the whole striatum was analyzed $\left(K^{2}=0.052 ; p=0.21\right)$. There was, however, a stronger correlation between basal DA and the symmetry in $D_{2} D A$ receptor binding within the dorsomcdial striatum $\left(R^{2}=0.284 ; p=0.0017\right)$

Although the AMPH RECOV animals as a group had a significant potentiation in basal and amphetamine-stimulated extracellular DA concentrations and a significant decrease in the $\mathrm{D}_{2}$ DA receptor upregulation, a correlation analysis was conducted to see if the magnitude of decreased amphetamine-induced turning (using all unilaterally lesioned animals) was predictive of the magnitude of the normalization of these pre- and postsynaptic DA measures. Both basal $\left(R^{2}=0.20 ; p=0.02\right)$ and amphetamine-stimulated $\left(R^{2}=0.18 ; p=0.03\right)$ extracellular DA concentrations within the denervated striatum were positively correlated with the magnitude of decreased amphetamineinduced turning behavior. The magnitude of decreased amphetamine-induced turning was also significantly correlated with enhanced symmetry in $\mathrm{D}_{2}$ DA receptor binding between the intact and DA-denervated striatum, with the greatest decrease in amphetamine-induced turning being associated with greater symmetry in $\mathrm{D}_{2}$ DA receptor binding (whole striatum: $R^{2}=$ $0.32, p=0.002$; dorsolateral striatum: $R^{2}=0.24, p=0.01$ ).

Analysis of the correlation between the magnitude of decreased apomorphine-induced turning and either extracellular DA concentrations or postsynaptic DA receptor binding for all animals with unilateral 6-OHDA lesions revealed that a decrease in apomorphine-induced rotational behavior is not associated with recovery of either pre- or postsynaptic DA function. There was no correlation between the percentage change in apomorphine-induced turning and basal extracellular DA concentrations within the denervated striatum $\left(R^{2}=0.008 ; p\right.$ $=0.65$ ), nor was there a correlation between changes in apomorphine-induced turning and the peak increase in striatal extracellular DA concentrations following amphetamine $\left(R^{2}=\right.$ $0.000006 ; p=1.0$ ). Analysis of the percentage change in apomorphine-induced turning and the percentage difference in $\mathrm{D}_{2}$ DA receptor binding for the whole striatum indicated that these events were not related $\left(R^{2}=0.034 ; p=0.35\right)$, nor was apomorphine-induced turning related to the percentage change in $\mathrm{D}_{2}$ DA receptors binding in the dorsomedial quadrant (Fig. $5 B$; $R^{2}=0.0025 ; p=0.9$ ). Our behavioral criteria, therefore, have not biased the relations between our neurochemical/binding measures and behavioral recovery. We conclude that normalization of extracellular striatal DA symmetry is associated with 
A)

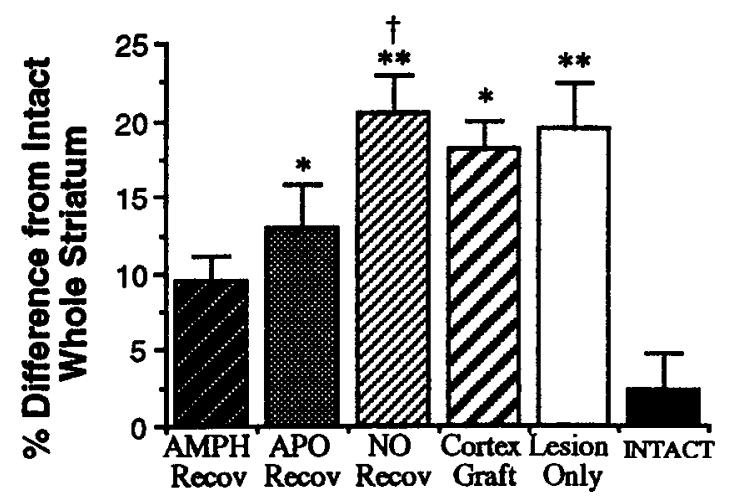

C)

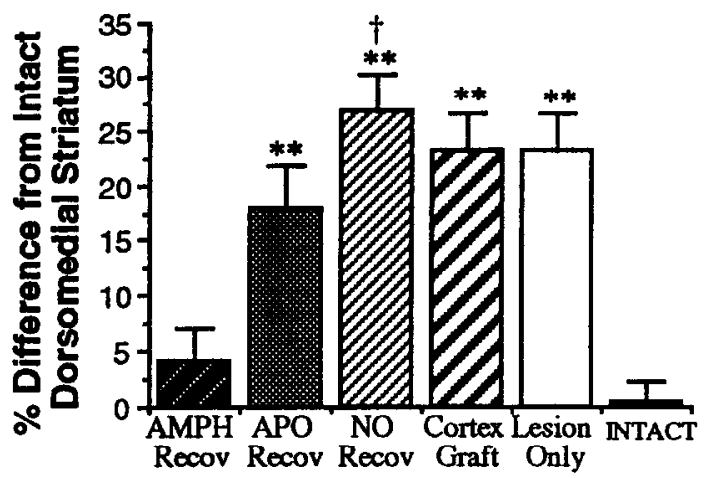

B)

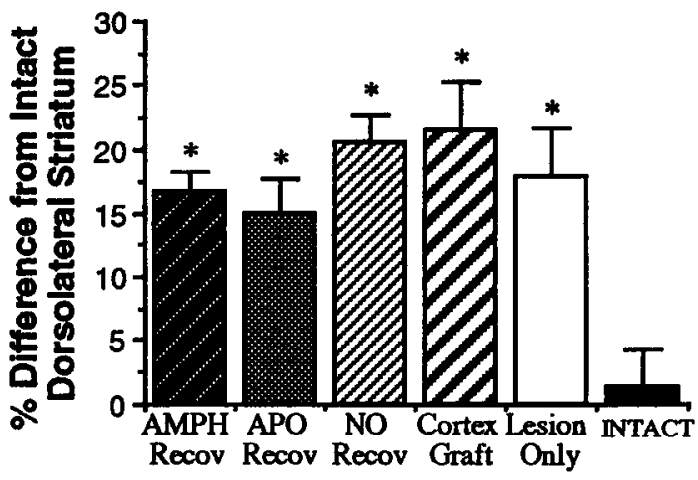

D)

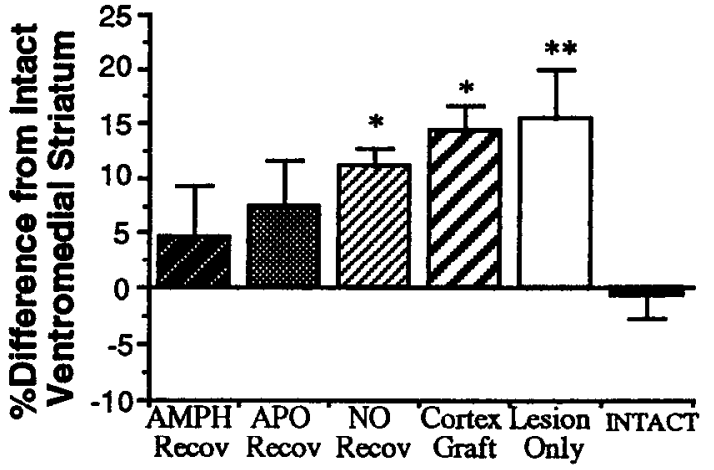

Figure 4. Percentage difference in $\mathrm{D}_{2} \mathrm{DA}$ receptor binding density observed between the denervated and contralateral intact striatum of the five groups with unilateral 6-OHDA lesions of the substantia nigra [(denervated - intact)/intact $\times 100 \%]$ compared to the left/right difference observed in INTACT animals. $A$, Percentage difference in $\mathrm{D}_{2} \mathrm{DA}$ receptor binding within the whole striatum. A significant difference was found among the six groups $[F(5,46)=7.869 ; p=0.0001] . B$, Percentage difference in $\mathrm{D}_{2} \mathrm{DA}$ receptor binding density within the dorsolateral striatum $[F(5,46)=$ $6.36 ; p=0.0001]$. $C$, Percentage difference in $\mathrm{D}_{2} \mathrm{DA}$ receptor binding density within the dorsomedial striatum $[F(5,46)=12.02 ; p=0.0001] . D$, Percentage difference in $\mathrm{D}_{2} \mathrm{DA}$ receptor binding within the ventromedial striatum $[F(5,46)=3.32 ; p=0.0121] .{ }^{* *}$, A significant increase in $\mathrm{D}_{2}$ DA reccptor binding was seen within the denervated striatum compared to the INT $\Lambda$ CT and AMPH RECOV groups $(p<0.05) . *, \Lambda$ significant increase in $D_{2}$ DA receptor binding was seen within the denervated striatum compared to INTACT animals $(p<0.05)$. $\dagger$, NO RECOV animals had a significantly greater increase in $D_{2}$ DA receptor binding within the denervated striatum compared to APO RECOV animals $(p<0.05)$.

Table 2. Saturation analysis of ${ }^{3} \mathrm{H}$-spiperone binding within the denervated and intact striatum

\begin{tabular}{|c|c|c|c|c|c|}
\hline Group & $\begin{array}{l}K_{d}, \\
\text { denervated } \\
\text { (nM) }\end{array}$ & $\begin{array}{l}K_{d}, \\
\text { intact } \\
\text { (nM) }\end{array}$ & $\begin{array}{l}B_{\max }, \\
\text { denervated } \\
\text { (pmol/ming } \\
\text { protein) } \\
\end{array}$ & $\begin{array}{l}B_{\max }, \\
\text { intact } \\
\text { (pmol/mg } \\
\text { protein) }\end{array}$ & $\begin{array}{l}\% \text { Difference } \\
\text { in } B_{\max }\end{array}$ \\
\hline $\begin{array}{l}\text { AMPH RECOV } \\
(n=4)\end{array}$ & $0.24 \pm 0.37$ & $0.24 \pm 0.034$ & $0.58 \pm 0.051$ & $0.57 \pm 0.050$ & $2.27 \pm 1.95$ \\
\hline $\begin{array}{l}\text { APO RECOV } \\
(n=3)\end{array}$ & $0.17 \pm 0.014$ & $0.17 \pm 0.021$ & $0.55 \pm 0.034$ & $0.50 \pm 0.025$ & $9.97 \pm 1.94$ \\
\hline $\begin{array}{l}\text { NO RECOV } \\
(n=4)\end{array}$ & $0.19 \pm 0.028$ & $0.25 \pm 0.035$ & $0.62 \pm 0.063$ & $0.53 \pm 0.041$ & $16.09 \pm 4.83^{*}$ \\
\hline $\begin{array}{l}\text { Cortex graft } \\
(n=4)\end{array}$ & $0.23 \pm 0.053$ & $0.22 \pm 0.022$ & $0.69 \pm 0.055$ & $0.59 \pm 0.018$ & $17.82 \pm 8.62^{* *}$ \\
\hline $\begin{array}{l}\text { Lesion only } \\
\qquad(n=3)\end{array}$ & $0.20 \pm 0.019$ & $0.20 \pm 0.021$ & $0.70 \pm 0.022$ & $0.61 \pm 0.037$ & $15.13 \pm 3.83^{*}$ \\
\hline $\begin{array}{r}\text { INTACT } \\
(n=4)\end{array}$ & $0.22 \pm 0.023$ & $0.24 \pm 0.014$ & $0.62 \pm 0.036$ & $0.64 \pm 0.044$ & $-3.63 \pm 2.07$ \\
\hline
\end{tabular}

Data are presented as mean \pm SEM.

*, Lesion only and NO RECOV animals expressed a significant increase compared to INTACT animals $(p<0.05)$.

**, Adrenal cortex-grafted animals had a significantly greater increase compared to AMPH RECOV and INTACT group $(p<0.05)$. 
A)

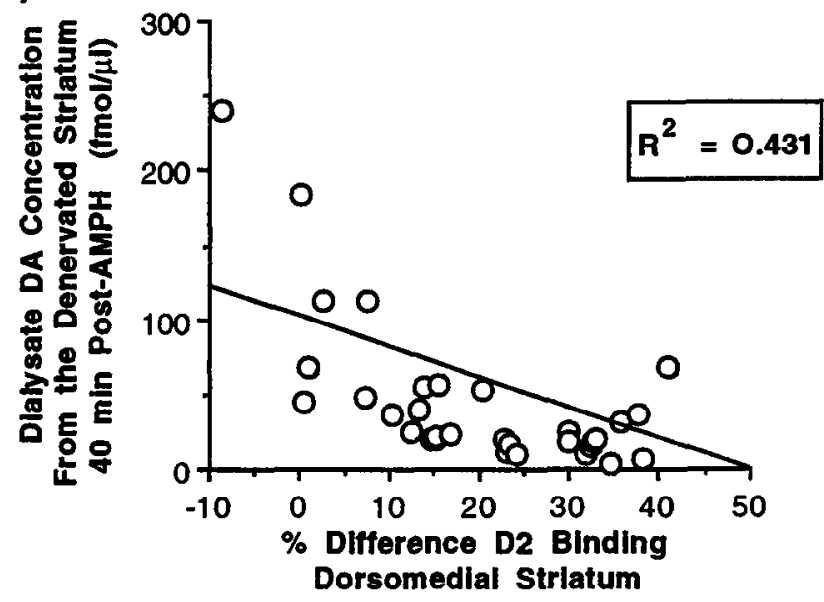

B)

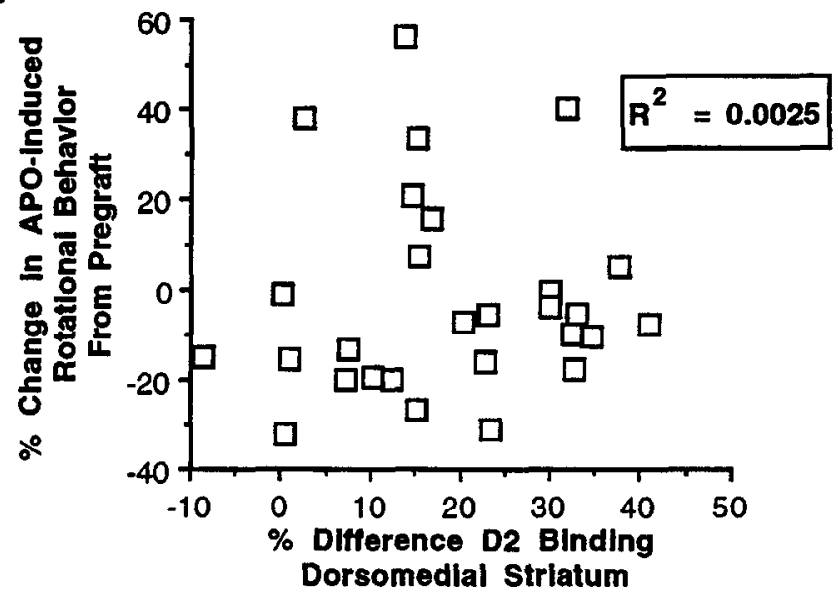

Figure 5. Correlation analysis between the lesion/graft effect on striatal $\mathrm{D}_{2}$ DA receptor binding symmetry and amphetamine $(A M P H)$-stimulated DA release during microdialysis within the denervated striatum $(A)$ or the percentage change in apomorphine $(A P O)$-induced rotational behavior $(R)$. $A$, The graft-induced restoration of amphetamine-stimulated DA release in the denervated striatum $40 \mathrm{~min}$ following amphetamine administration and the percentage difference in $D_{2}$ binding densities within the dorsomedial striatum are highly correlated. $B$, There is no correlation, however, between the magnitude of the percentage change in apomorphine-induced turning behavior and the graft-induced enhancement in striatal $D_{2}$ DA binding symmetry.

recovery of the symmetry in striatal $\mathrm{D}_{2} \mathrm{DA}$ receptor binding, and the symmetry in both these measures is restored in AMPH RECOV animals.

\section{TH $m R N A$ in situ hybridization}

Examination of graft survival with TH mRNA in situ hybridization and/or hematoxylin and eosin staining revealed that surviving adrenal medulla grafts, but not adrenal cortex grafts, expressed a positive signal for TH mRNA (see Fig. 6). Of the seven rats in the AMPH RECOV group that were analyzed in this manner, four animals had surviving adrenal medulla grafts within the lateral ventricle adjacent to the denervated striatum and three animals had no surviving grafts. As stated above, the time lag between the last behavioral test and obtaining the tissue for histology was $2-4$ months. Thus, it is possible that there was graft rejection after the behavioral tests in some animals. Three
Table 3. Substantia nigra pars compacta lesion size

\begin{tabular}{ll} 
Group & Lesion size $^{a}$ \\
\hline AMPH RECOV $(n=9)$ & $97.56 \pm 0.84 \%$ \\
APO RECOV $(n=13)$ & $96.12 \pm 0.66 \%$ \\
NO RECOV $(n=12)$ & $97.54 \pm 0.63 \%$ \\
Cortex graft $(n=8)$ & $96.59 \pm 0.88 \%$ \\
Lesion only $(n=12)$ & $96.34 \pm 0.77 \%$
\end{tabular}

${ }^{a}$ Expressed as percentage decrease from cell number in contralateral intact substantia nigra, mean \pm SEM.

of four surviving grafts expressed positive signal for TH mRNA. One of these animals had a graft within the denervated striatum; a glial scar was observed surrounding the graft but surviving chromaffin cells (with TH signal) and connective tissue were seen within the graft itself. Four of the six APO RECOV animals examined also had surviving grafts within the lateral ventricle with two animals showing no evidence of graft survival. Two of the four surviving adrenal medulla grafts in this group were positive for TH mRNA. Within the NO RECOV group only four out of eight animals were observed to have an adrenal medulla graft within the lateral ventricle adjacent to the denervated striatum but very little to no signal was observed for $\mathrm{TH}$ mRNA. Of the remaining four NO RECOV animals, one had no surviving graft, and two had a graft within the cerebral cortex and one was caudal to the intended graft site adhered to the hippocampal commissure (see Curran and Becker, 1991). Hematoxylin and eosin staining of tissue sections from all six animals that had received adrenal cortex grafts showed that only two of the six had surviving grafts. Both of these animals had grafts located within the lateral ventricle and neither graft had any visible chromaffin cells mixed in with the cortical tissue. Further, one of the grafts was processed for TH in situ hybridization but no signal was observed.

Hybridization specificity was examined with a TH riboprobe, the corresponding sense probe, and RNase A pretreatment in adjacent $10 \mu \mathrm{m}$ coronal sections of an animal with a surviving adrenal medulla graft (Fig. 7). This animal was not represented in the above behavioral, neurochemical, or receptor binding analyses due to an incomplete substantia nigra lesion.

\section{Histology and cell counts}

Histological analysis indicated that the dialysis probes were within the striatum for all the data shown. Some probes were found to be within the lateral ventricle; the data from those probes were not included in the microdialysis results. This resulted in the exclusion of five animals (AMPH RECOV, $n=2$; APO RECOV, $n=1$; NO RECOV, $n=2$ ).

Cell counts within both the intact and lesioned substantia nigra zona compacta indicated that all animals had greater than $90 \%$ destruction of DA cells in this area. Table 3 indicates that there was no significant difference in lesion size among the five groups with unilateral substantia nigra lesions. All groups had a mean lesion size greater than $95 \%$. The substantia nigra lesions were confirmed in a subset of animals from all lesioned groups using TH in situ hybridization. Analysis of the number of THpositive neurons within the adjacent ventral tegmental area of these animals showed varying degrees of DA neuron loss with no animal having a complete lesion of this structure. The variability in ventral tegmental area damage was comparable for all five of the lesioned groups. 

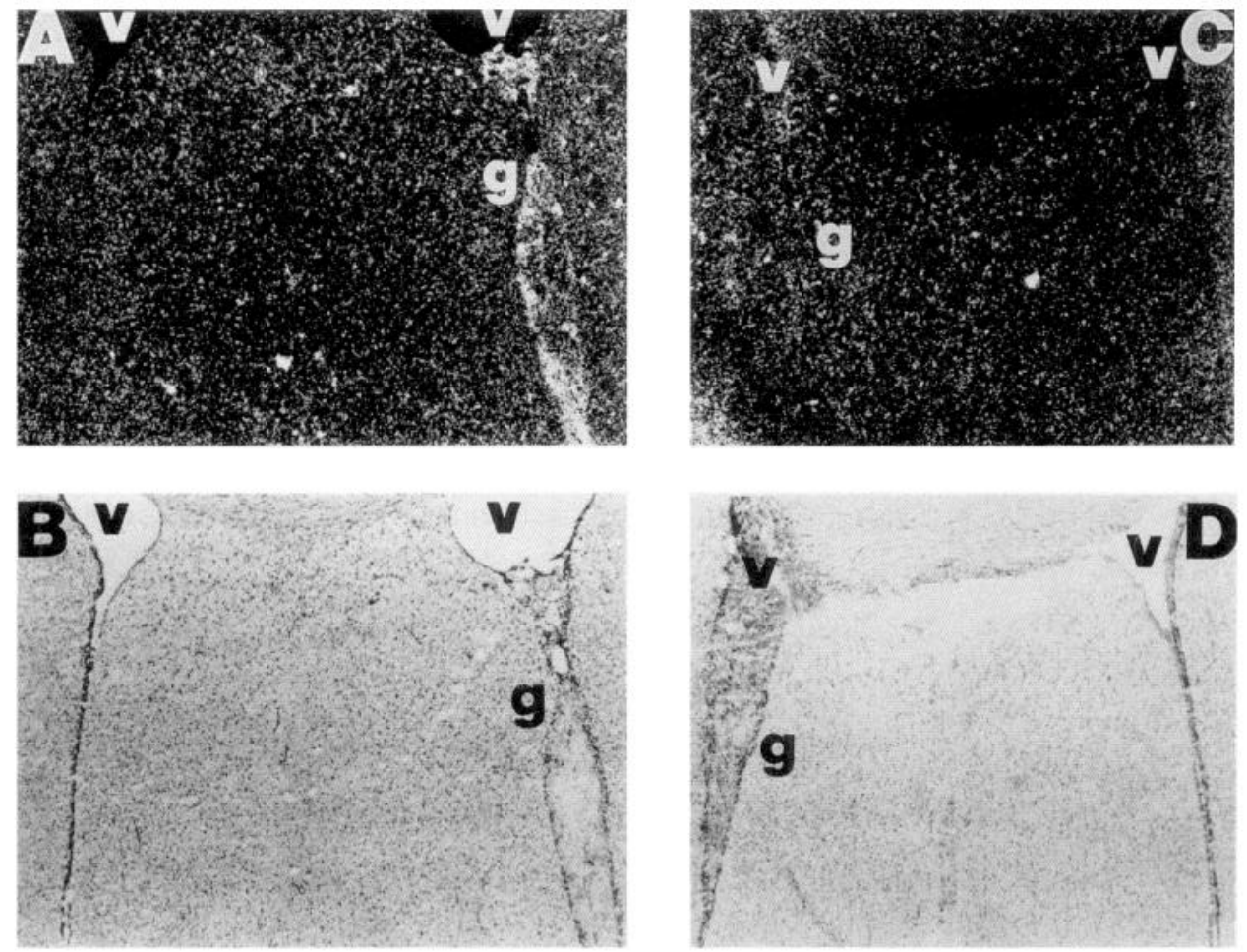

Figure 6. TH mRNA expression within an intraventricular adrenal medulla graft ( $A$ and $B ; 40 \times$ magnification) or adrenal cortex graft ( $C$ and $D$; $40 \times$ magnification). Twenty micrometer coronal sections were hybridized with an ${ }^{35} \mathrm{~S}-\mathrm{TH}$ oligonucleotide probe and stained with hematoxylin and eosin. A dark-field photomicrograph of an adrenal medulla graft $(A)$ is shown in comparison to an adrenal cortex graft (C). Note that only the adrenal medulla graft expresses positive signal for $\mathrm{TH}$ mRNA. The corresponding bright-field photomicrograph of the adrenal medulla graft is shown in $B$, and the adrenal cortex graft is shown in $D . v$, lateral ventricle; $g$, graft.

\section{Discussion}

The results of the experiments presented here indicate that those animals with adrenal medulla grafts that show a decrease in the behavioral response to amphetamine (i.e., the AMPH RECOV group) have the most effective grafts. The adrenal medulla graftinduced decrease in the behavioral response to amphetamine is associated with the restoration of striatal pre- and postsynaptic DA symmetry. Basal and amphetamine-stimulated extracellular DA concentrations within the DA-denervated striatum adjacent to adrenal medulla grafts in animals with AMPH RECOV were significantly enhanced relative to all other unilaterally DA-denervated groups and were not significantly different from intact striatum. The bilateral neurochemical analysis conducted indicates that the enhanced extracellular DA concentrations within the denervated striatum of AMPH RECOV animals restore the balance in presynaptic DA function between the two striata. The symmetry in striatal $\mathrm{D}_{2} \mathrm{DA}$ receptor binding density was also restored in this group. The graft-induced restoration of striatal $\mathrm{D}_{2}$ DA receptor binding symmetry was strongly correlated with the increased extracellular striatal DA concentrations. In contrast to the AMPH RECOV animals, extracellular striatal DA within the DA-denervated striatum was not augmented in APO RECOV animals, with the extracellular DA concentrations in these animals not differing significantly from lesion-only animals. The APO RECOV animals also did not show a substantial decrease in the lesion-induced $\mathrm{D}_{2}$ DA receptor upregulation. Furthermore, there was no correlation between $\mathrm{D}_{2} \mathrm{DA}$ receptor symmetry and the magnitude of the graft-induced decrease in the behavioral response to apomorphine. These results demonstrate that only adrenal medulla grafts that promote AMPH RECOV ameliorate the asymmetry in pre- and postsynaptic DA measures between the two striata, suggesting that AMPH RE$\mathrm{COV}$ animals are expressing recovery of DA function and that APO RECOV animals are not.
The normalization of striatal presynaptic DA symmetry in AMPH RECOV versus APO RECOV animals may involve the accessibility of graft and/or peripheral DA to the denervated striatum. Previously we have shown that animals with behaviorally effective adrenal medulla grafts have a disrupted bloodbrain barrier (BBB) at the graft/striatum interface (Curran and Becker, 1991). In contrast, the BBB is intact in animals with NO RECOV following adrenal medulla grafts, in animals with adrenal cortex grafts, in animals with unilateral 6-OHDA lesions and no graft, and in the intact striatum of all the DA-denervated animals. Disruption of the BBB may therefore be necessary for both AMPH RECOV and APO RECOV. In the previous experiment we demonstrated that peripherally administered DA has greater access to the striatum in AMPH RECOV animals than in APO RECOV animals, so restoration of extracellular DA concentrations may be related to the ease with which DA can penetrate the striatum.

Robinson and Whishaw (1988) have demonstrated that the extent of striatal DA denervation affects basal striatal DA concentrations. We found no significant difference in lesion size among the groups with unilateral 6-OHDA lesions. A disparity in the size of the substantia nigra lesion, therefore, was not responsible for the difference in striatal extracellular DA concentrations between the AMPH RECOV group and the other lesion/grafted groups including the APO RECOV group. However, in all groups there were surviving DA neurons within the ventral tegmental area. This finding suggests that one mechanism by which behaviorally effective adrenal medulla grafts may enhance extracellular striatal DA is to promote sprouting from remaining midbrain DA neurons that project to sites adjacent to the DA-denervated striatum. This phenomenon has been suggested previously by Bohn et al. (1987), who examined adrenal medulla grafts in MPTP-treated mice. A systematic analysis of TH-positive fibers within the striatum of the animals in the present study was not possible to conduct simultaneously 

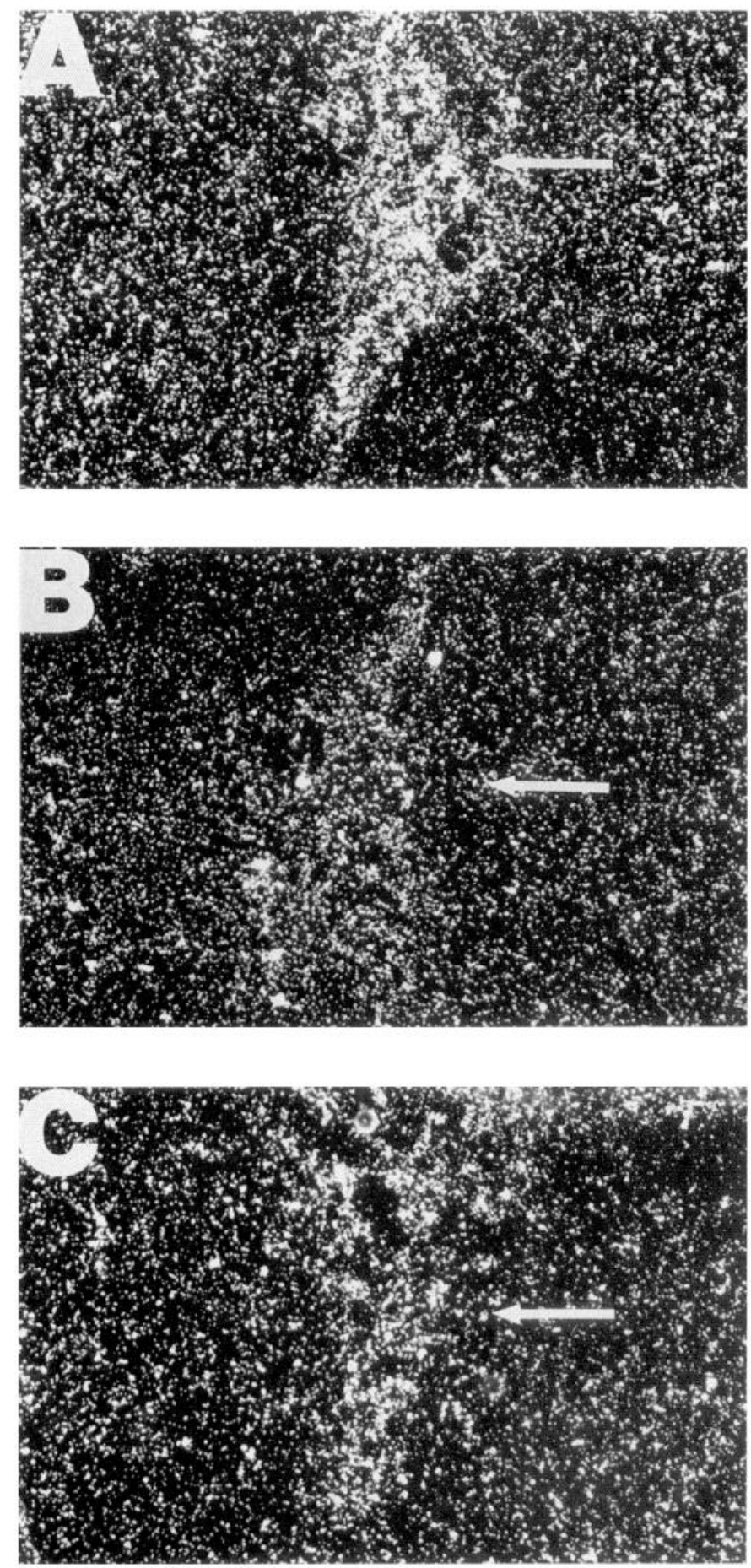

Figure 7. Dark-field photomicrographs ( $80 \times$ magnification) of $10 \mu \mathrm{m}$ coronal sections through an intraventricular adrenal medulla graft hybridized with a ${ }^{35} \mathrm{~S}$-TH cRNA probe: $A$, antisense probe; $B$, sense probe; $C$, antisense probe with RNase A pretreatment. Arrows point to the graft located in the lateral ventricle.

with the receptor binding and in situ hybridization methods. However, future studies will examine possible differences in this measure between behaviorally distinct groups following adrenal medulla grafts to help determine if graft-induced sprouting is related to the different behavioral profiles we observe.

The TH mRNA in situ hybridization experiments were conducted to determine if surviving grafts were still capable of producing catecholamines. The results from these experiments need to be interpreted cautiously, however, since $2-4$ months elapsed between the behavioral analysis and the removal of the brain. In general, all groups had animals with no surviving grafts, although the two groups with behavioral recovery, AMPH RECOV and APO RECOV, had a higher survival rate and/or proper graft placement than those animals with NO RECOV following adrenal medulla grafts. In a previous study, it was shown that there is no correlation between the number of surviving chromaffin cells and behavioral recovery (Takashima et al., 1992). In the present study, those animals with surviving adrenal medulla grafts and NO RECOV tended to have grafts that were misplaced in the cerebral cortex or not adhered to the wall of the ventricle adjacent to the denervated striatum. In contrast, all surviving grafts in the AMPH RECOV and APO RECOV animals were located within the lateral ventricle adjacent to the denervated striatum (one AMPH RECOV animal did have a surviving graft within the denervated striatum itself). Appropriate graft placement, therefore, appears to be necessary for behavioral recovery. Furthermore, a large proportion of the surviving adrenal medulla grafts associated with behavioral recovery displayed positive signal for TH mRNA indicating that catecholamine production was possible. One animal with a surviving adrenal cortex graft was processed for TH mRNA; this animal did not express a positive TH mRNA signal indicating that the signal was tissue specific. The presence of TH mRNA in a subset of the surviving adrenal medulla grafts, therefore, indicates that the graft could be the potential source of DA to the denervated striatum.

We found enhanced symmetry in $\mathrm{D}_{2}$ DA receptor binding within the AMPH RECOV group but not the APO RECOV group. This is rather surprising at first glance since previous reports have linked $D_{2}$ receptor upregulation with the intensity of apomorphine-induced turning (Creese et al., 1977). Our findings, however, indicate that the enhanced $\mathrm{D}_{2}$ DA receptor binding found following unilateral striatal DA depletions does not correlate with the phenomenon of behavioral supersensitivity to DA agonists. In this experiment, the AMPH RECOV group includes animals with a graft-induced decrease in the behavioral response to both amphetamine and apomorphine or just in response to amphetamine. The neurochemical changes as well as the decrease in $\mathrm{D}_{2}$ DA receptor upregulation observed in the AMPH RECOV group occurred even in those animals that did not express decreased apomorphine-induced rotational behavior. Together with the significantly smaller decrease in $\mathrm{D}_{2} \mathrm{DA}$ receptor upregulation seen in the APO RECOV animals these results suggest that the $D_{2}$ DA receptor asymmetry does not directly mediate apomorphine-induced rotational behavior. In fact, we observed a double dissociation between behavioral supersensitivity and DA receptor upregulation. Within the dorsomedial striatum, those animals that showed a decrease exclusively in the behavioral response to apomorphine (APO RECOV) did not show a decrease in $\mathrm{D}_{2} \mathrm{DA}$ receptor upregulation and, conversely, a subset of the AMPH RECOV animals that had no change in apomorphine-induced turning, showed a normalization in $\mathrm{D}_{2}$ DA receptor binding densities.

Other studies using different experimental paradigms support the idea that enhanced $\mathrm{D}_{2}$ DA receptor binding does not mediate apomorphine-induced rotational behavior. LaHoste and Marshall (1991) examined the $D_{2}$ DA receptor upregulation that occurs following a unilateral substantia nigra lesion in conjunction with the upregulation that occurs following chronic treat- 
ment with $D_{2}$ antagonists. Unilaterally DA-denervated rats exhibited vigorous contralateral rotational behavior following DA agonist treatment that was not altered by subsequent chronic treatment with a $\mathrm{D}_{2}$ antagonist; even though both the intact and DA-denervated striatum showed comparable increases in $D_{2}$ DA receptor binding following DA antagonist treatment. Mileson et al. (1991) compared animals with unilateral and bilateral $\mathrm{D} \Lambda$ depletions and also reported a dissociation between $\mathrm{D}_{2} \mathrm{DA}$ receptor upregulation and behavioral supersensitivity. The present results and the two additional studies discussed above provide strong evidence, from three very different experimental paradigms, that the upregulation of $\mathrm{D}_{2} \mathrm{DA}$ receptors in the DAdenervated striatum does not directly mediate the behavioral supersensitivity that occurs following striatal DA denervation.

While the lesion-induced $\mathrm{D}_{2} \mathrm{DA}$ receptor upregulation is not closely associated with behavioral supersensitivity (apomorphine-induced turning), it is sensitive to extracellular striatal DA concentrations. Enhanced extracellular DA concentrations within the DA-denervated striatum were highly correlated with the enhanced symmetry in $D_{2} D A$ receptor binding, and the symmetry in both pre- and postsynaptic DA measures was restored in the AMPH RECOV animals. These findings indicate that only adrenal medulla grafts that promote AMPH RECOV are enhancing measures of striatal DA activity, suggesting that this type of recovery will be more beneficial in terms of treatment for Parkinson's disease.

In the present study, we observed an average decrease of $22 \%$ in amphetamine-induced rotational behavior by adrenal medulla grafted animals that expressed recovery to this drug. A more robust recovery in amphetamine-induced turning has been ubserved with intrastriatal transplants of fetal substantia nigra tissue. One possible reason for the smaller decrease seen in the present study and in previous work with adrenal medulla tissue is the location of the graft in the lateral ventricle. In the present study, using in vivo microdialysis we measured extracellular DA concentrations within the medial striatum adjacent to the ventricle. It is unknown if extracellular DA concentrations are enhanced in AMPH RECOV animals at sites more distal from the graft. Since the normalization of $D_{2} \mathrm{DA}$ receptor binding was scen in the dorsomedial striatum but not in the dorsolateral striatum of these animals, it is likely that intraventricular adrenal medulla grafts that promote AMPH RECOV are not enhancing extracellular DA concentrations within the dorsolateral striatum. In studies using fetal mesencephalic tissue transplants, graft placement has been found to be critical for the reduction of amphetamine-induced turning (Dunnett et al., 1981; Mandel et al., 1990). In these studies, grafts that were placed dorsally in the center of the striatum ameliorated amphetamine-induced turning behavior whereas grafts placed in the ventrolateral striatum did not. The centrally placed fetal tissue grafts are capable of providing a new DA source to the dorsomedial and dorsolateral striatum whereas intraventricular adrenal medulla grafts appear to affect only the dorsomedial striatum. Thus, for adrenal medulla grafts in the lateral ventricle to produce even a $22 \%$ decrease in amphetamine-induced turning reflects a significant functional recovery.

In previous studies we have reported that the decrease in apomorphine-induced turning after intraventricular adrenal medulla grafts is correlated with an increase in serum DA concentrations (Becker and Freed, 1988a,b). In a recent study this phenomena was once again replicated (Takashima et al., 1992). In a very comprehensive study that included adrenalectomized and adrenal-intact animals with intraventricular grafts of adrenal medulla, sciatic nerve, or a sham graft, serum DA was increased in all groups of adrenal-intact rats, but not in any of the adrenalectomized groups. There was a significant decrease, however, in apomorphine-induced turning in both adrenal-intact and adrenalectomized rats with adrenal medulla grafts, but not in the control groups. Thus, in spite of the correlation between serum DA and the decrease in apomorphine-induced turning after adrenal medulla grafts, an increase in serum DA is neither necessary nor sufficient to induce a decrease in apomorphine-induced rotational behavior (Takishima et al., 1992). The present study revealed that decreased apomorphine-induced turning is not associated with increased extracellular DA concentrations within the DA-denervated striatum. Together, these findings suggests that adrenal medulla graft derived substances other than DA, such as trophic factors (see Strömberg et al., 1985; Freed et al., 1990, for review), may be involved in the reduction of apomorphine-induced turning behavior. It has been shown that intraventricular or intrastriatal adrenal medulla grafts promote a greater decrease in apomorphine-induced rotational behavior when the graft site is chronically treated with NGF (Strömberg et al., 1985; Pezzoli et al., 1988). The intraventricular or intrastriatal infusion of NGF alone, however, had no effect on apomorphine-induced rotational behavior. These studies provide evidence that trophic factors are able to influence apomorphine-induced turning behavior. Furthermore, adrenal medulla grafts have been found to contain a number of trophic substances including basic fibroblast growth factor (Blottner and Unsicker, 1989) and administration of this growth factor has been has been shown to induce sprouting of dopaminergic neurons in MPTP treated mice (Otto and Unsicker, 1990).

Our results show that the 6-OHDA lesion-induced upregulation of $\mathrm{D}_{2}$ DA receptors is not reversed following adrenal medulla grafts that reduce apomorphine-induced rotational behavior. On the other hand, the decrease in apomorphine-induced turning may reflect a reorganization of the association between striatal DA receptors and their effector system or a reassociation between $D_{1}$ and $D_{2} D A$ receptors. Research by Ariano (1989) has shown that following unilateral striatal DA denervation there is a dissociation of $D_{1}$ DA receptor binding and CAMP immunoreactivity localized in striatal neurons. Furthermore, there is normally a synergistic relationship between $D_{1}$ and $D_{2}$ DA receptors that is uncoupled following striatal DA denervation (Breese et al., 1987; Sonsalla et al., 1988). Adrenal medulla graft-induced changes in either measure of DA receptor function would not be noted with the methods employed in this study.

Future studies need to determine whether a decrease only in apomorphine-induced turning is truly functional recovery or if it is detrimental. It has been suggested that the increase in postsynaptic DA receptor sensitivity measured by apomorphineinduced turning is a compensatory mechanism that enhances the functional activity of the remaining presynaptic DA terminals in unilaterally DA-denervated rats, producing spontaneous recovery of function (Marshall, 1979). The absencc of increased symmetry in extracellular striatal DA concentrations within the APO RECOV group is in contrast to our previous findings (Becker et al., 1990b) where the asymmetry in extracellular DA was decreased in animals that showed decreased apomorphine-induced turning. In this previous study, the decreased neurochemical asymmetry included a decrease in ex- 
tracellular DA within the contralateral striatum and an increase within the DA-denervated striatum. In the present study there was a nonsignificant trend for extracellular DA concentrations to be decreased in the contralateral intact striatum of APO RECOV animals (Fig. 2) and there was no increase within the DA-dencrvated striatum. The number of animals included in the present study is almost three times greater than in the previous study, so it does not seem likely that the symmetry of extracellular striatal DA is promoting APO RECOV. In light of these findings, APO RECOV may actually be working against the spontaneous recovery induced by the postsynaptic compensatory changes. In other words, if a decrease in postsynaptic DA receptor supersensitivity is occurring in APO RECOV animals (as the decrease in apomorphine-induced turning behavior suggests), then the absence of increased presynaptic DA activity would actually increase the asymmetry between the intact and DA-denervated striatum. A decrease in apomorphine-induced turning, in the absence of decreased amphetamine-induced turning may, therefore, represents an adverse effect of adrenal medulla grafts. Future studies need to examine the effect of adrenal medulla grafts (and other graft tissues) on both amphetamineand apomorphine-induced rotational bchavior so as to cxaminc fully the potential of the grafts to promote recovery of function.

In conclusion, the results reveal that only adrenal medulla grafts that promote AMPH RECOV restore the balance between the intact and DA-denervated striatum in measures of pre- and postsynaptic DA function. In addition, the simultaneous analysis of pre- and postsynaptic DA measures in this study provides strong evidence that striatal $\mathrm{D}_{2} \mathrm{DA}$ receptor upregulation is linked to striatal extracellular DA concentrations and both of these measures are normalized in AMPH RECOV animals. The distinct behavioral and neurological effects of adrenal medulla grafts reported here illustrate the value of this method for investigating the complex alterations that occur within the striatum following DA denervation and subsequent functional recovery. Further research on the mechanism(s) through which pre- and postsynaptic striatal DA activity is enhanced in animals with AMPH RECOV has strong potential to lead to better clinical success with adrenal medulla grafts and/or the development of more effective treatment paradigms for Parkinson's disease.

\section{References}

Ariano MA (1989) Long-term changes in striatal Dl dopamine receptor distribution after dopaminergic deafferentation. Neuroscience 32:203-212.

Becker JB, Freed WJ (1988a) Adrenal medulla grafts enhance functional activity of the striatal dopamine system following substantia nigra lesions. Brain Res 462:401-406.

Becker JB, Freed WJ (1988b) Neurochemical correlates of behavioral changes following intraventricular adrenal medulla grafts: intraventricular microdialysis in freely moving rats. Prog Brain Res 78:527533.

Becker JB, Curran EJ, Freed WJ (1990a) Adrenal medulla graft induced recovery of function in an animal model of Parkinson's disease: possible mechanisms of action. Can J Psychol 44:293-310.

Becker JB, Curran EJ, Freed WJ, Poltorak M (1990b) Mechanisms of action of adrenal medulla grafts: the possible role of peripheral and central dopamine systems. Prog Brain Res 82:499-507.

Blottner D, Unsicker K (1989) Spatial and temporal patterns of neurotrophic activities in rat adrenal medulla and cortex. Dev Brain Res 48:243-253.

Bohn MC, Cupit L, Marciano F, Gash DM (1987) Adrenal medulla grafts enhance recovery of striatal dopaminergic fibers. Science 237: 913-916.

Breese GR, Duncan GE, Napier TC, Bondy SC, Iorio LC, Mueller RA (1987) 6-Hydroxydopamine treatments enhance behavioral re- sponses to intracerebral microinjection of D1- and D2-dopamine agonists into nucleus accumbens and striatum without changing dopamine antagonist binding. J Pharmacol Exp Ther 240:167-176

Buonamici M, Maj R, Pagani F, Rossi AC, Khazan N (1986) Tremor at rest episodes in unilaterally 6-OHDA substantia nigra lesioned rats: EEG-EMG and behavior. Neuropharmacology 25:323-325.

Creese I, Burt DR, Snyder SH (1977) Dopamine receptor binding enhancement accompanies lesion-induced behavioral supersensitivity. Science 197:596-598.

Curran EJ, Becker JB (1991) Changes in blood-brain barrier permeability are associated with behavioral and neurochemical indices of recovery following intraventricular adrenal medulla grafts in an animal model of Parkinson's disease. Exp Neurol 114:184-192.

Dunnett SB, Bjorklund A, Stenevi U, Iversen SD (1981) Grafts of embryonic substantia nigra reinnervating the ventrolateral striatum ameliorate sensorimotor impairments and akinesia in rats with 6-OHDA lesions of the nigrostriatal pathway. Brain Res 229:209217.

Freed WJ, Morihisa JM, Spoor E, Hoffer BJ, Olson L, Seiger $\AA$, Wyatt RJ (1981) Transplanted adrenal chromaffin cells in rat brain reduce lesion-induced rotational behavior. Nature 292:351-352.

Freed WJ, Poltorak M, Becker JB (1990) Intracerebral adrenal medulla grafts: a review. Exp Neurol 110:139-166.

Glick SD, Shapiro RM (1985) Functional and neurochemical mechanisms of cerebral lateralization in rats. In: Cerebral lateralization in nonhuman species (Glick SD, ed), pp 157-183. Orlando: Academic.

Gulley RL, Wood RL (1971) The fine structure of the neurons in the rat substantia nigra. Tissue Cell 3:675-690.

Gundersen HJG, Bagger P, Bendtsen TF, Evans SM, Korbo L, Marcussen N, Møller A, Nielsen K, Nyengaard JR, Pakkenberg B, Sorensen FB, Vesterby A, West MJ (1988) The new stereological tools: disector, fractionator, nucleator and point sampled intercepts and their use in pathological research and diagnosis. APMIS 96:857-881.

LaHoste GJ, Marshall JF (1991) Chronic eticlopride and dopamine denervation induce equal nonadditive increases in striatal D2 reccptor density: autoradiographic evidence against the dual mechanism hypothesis. Neuroscience 41:473-481.

Mandel RJ, Brundin P, Björklund A (1990) The importance of graft placement and task complexity for transplant-induced recovery of simple and complex sensorimotor deficits in dopamine denervated rats. Eur J Neurosci 2:888-894.

Marshall JF (1979) Somatosensory inattention after dopamine-depleting intracerebral 6-OHDA injections: spontaneous recovery and pharmacological control. Brain Res 177:311-324.

Mileson BE, Lewis MH, Mailman RB (1991) Dopamine receptor 'supersensitivity' occurring without receptor up-regulation. Brain Res 561:1-10.

Otto D, Unsicker K (1990) Basic FGF reverses chemical and morphological deficits in the nigrostriatal system of MPTP treated mice. J Neurosci 10:1912-1921.

Pan HS, Frey KA, Young AB, Penney JB (1983) Changes in $\left[{ }^{3} \mathrm{H}\right]$ muscimol binding in substantia nigra, entopeduncular nucleus, globus pallidus, and thalamus after striatal lesions as demonstrated by quantitative receptor autoradiography. J Neurosci 3:1189-1 198.

Pezzoli G, Fahn S, Dwork A, Truong DD, de Yebenes JG, JacksonLewis V, Herbert J, Cadet JL (1988) Non-chromaffin tissue plus nerve growth factor reduces experimental parkinsonism in aged rats. Brain Res 459:398-403.

Pycock CJ (1980) Turning behavior in animals. Neuroscience 5:461514.

Richfield EK, Young AB, Penney JB (1987) Comparative distribution of dopamine D-1 and D-2 receptors in the basal ganglia of turtles, pigcons, rats, cats, and monkeys. J Comp Neurology 262:446-463.

Robinson TE, Becker JB (1983) The rotational behavior model: asymmetry in the effects of unilateral 6-OHDA lesions of the substantia nigra in rats. Brain Res 264:127-131.

Robinson TE, Becker JB (1986) Enduring changes in brain and behavior produced by chronic amphetamine administration: a review and evaluation of animals models of amphetamine psychosis. Brain Res 11:157-198.

Robinson TE, Camp DM (1991) The feasibility of repeated microdialysis for within-subjects design experiments: studies on the mesostriatal dopamine system. In: Microdialysis in the neurosciences (Robinson TE, Justice JB Jr, eds), pp 189-234. Amsterdam: Elsevier. Robinson TE, Whishaw IQ (1988) Normalization of extracellular dopamine in striatum following recovery from a partial unilateral 
6-OHDA lesion of the substantia nigra: a microdialysis study in freely moving rats. Brain Res 450:209-224.

Robinson TE, Becker JB, Presty SK (1982) Long-term facilitation of amphetamine-induced rotational behavior and striatal dopamine release produced by a single exposure to amphetamine: sex differences. Brain Res 253:231-241.

Sonsalla PK, Manzino L, Heikkila RE (1988) Interactions of DI and D2 dopamine receptors on the ipsilateral vs. contralateral side in rats with unilateral lesions of the dopaminergic nigrostriatal pathway. J Pharmacol Exp Ther 247:180-185.

Strömberg I, Herrara-Marschitz M, Ungerstedt U, Ebendal T, Olson L (1985) Chronic implants of chromaffin tissue into the dopaminedenervated striatum. Effects of NGF on graft survival, fiber growth and rotational behavior. Exp Brain Res 60:335-349.

Takashima H, Poltorak M, Becker JB, Freed WJ (1992) Fffects of adrenal medulla grafts on plasma catecholamines and rotational behavior. Exp Neurol 118:24-34.
Ungerstedt $U$ (1971a) Striatal dopamine release after amphetamine or nerve degeneration revealed by rotational behavior. Acta Physiol Scand [Suppl] 367:49-68.

Ungerstedt $U$ (1971b) Postsynaptic supersensitivity after 6-hydroxydopamine induced degeneration of the nigro-striatal dopamine system. Acta Physiol Scand [Suppl] 367:69-93.

Watson S, Patel P, Burke S, Herman J, Schafer M, Kwak S (1988) In situ hybridization of mRNA in nervous tissue: a primer. In: 1988 Society for Neuroscience short course 1 syllabus (Sundermann A, ed), pp 4-29. Washington, DC: Society for Neuroscience.

Weiner WJ, Lang AE (1989) Movement disorders: a comprehensive survey. New York: Futura.

Zigmond MJ, Abercrombie ED, Berger TW, Grace AA, Stricker EM (1990) Compensations after lesions of central dopaminergic neurons: some clinical and basic implications. Trends Neurosci 13:290-296. 